\title{
Pandanus odoratissimus (Kewda): A Review on Ethnopharmacology, Phytochemistry, and Nutritional Aspects
}

\author{
Prafulla P. Adkar ${ }^{1,2}$ and V. H. Bhaskar ${ }^{3}$ \\ ${ }^{1}$ Department of Pharmacology, JSPM's Jayawantrao Sawant College of Pharmacy and Research, University of Pune, Pune, \\ Maharashtra 411028, India \\ ${ }^{2}$ Vinayaka Missions University, Sankari Main Road, NH-47, Ariyanoor, Salem, Tamil Nadu 636308, India \\ ${ }^{3}$ Department of Pharmaceutical Medicinal Chemistry, Gahlot Institute of Pharmacy, Plot No. 59, Sector No. 14, Kopar khairane, \\ Navi Mumbai, Maharashtra 400709, India \\ Correspondence should be addressed to Prafulla P. Adkar; prafi.phd@gmail.com
}

Received 6 February 2014; Revised 9 June 2014; Accepted 10 June 2014; Published 22 December 2014

Academic Editor: Berend Olivier

Copyright (c) 2014 P. P. Adkar and V. H. Bhaskar. This is an open access article distributed under the Creative Commons Attribution License, which permits unrestricted use, distribution, and reproduction in any medium, provided the original work is properly cited.

\begin{abstract}
Pandanus odoratissimus Linn. (family: Pandanaceae) is traditionally recommended by the Indian Ayurvedic medicines for treatment of headache, rheumatism, spasm, cold/flu, epilepsy, wounds, boils, scabies, leucoderma, ulcers, colic, hepatitis, smallpox, leprosy, syphilis, and cancer and as a cardiotonic, antioxidant, dysuric, and aphrodisiac. It contains phytochemicals, namely, lignans and isoflavones, coumestrol, alkaloids, steroids, carbohydrates, phenolic compounds, glycosides, proteins, amino acids as well as vitamins and nutrients, and so forth. It is having immense importance in nutrition. A $100 \mathrm{~g}$ edible Pandanus pericarp is mainly comprised of water and carbohydrates ( 80 and $17 \mathrm{~g}$, resp.) and protein $(1.3 \mathrm{mg})$, fat $(0.7 \mathrm{mg})$, and fiber (3.5 g). Pandanus fruits paste provides 321 kilocalories, protein $(2.2 \mathrm{~g})$, calcium $(134 \mathrm{mg})$, phosphorus (108 $\mathrm{mg})$, iron $(5.7 \mathrm{mg})$, thiamin $(0.04 \mathrm{mg})$, vitamin C $(5 \mathrm{mg}$ ), and beta-carotene (19 to $19,000 \mu \mathrm{g}$ ) (a carotenoid that is a precursor to vitamin A). Pandanus fruit is an important source of vitamins $C, B_{1}, B_{2}, B_{3}$, and so forth, usually prepared as a Pandanus floured drink. Traditional claims were scientifically evaluated by the various authors and the phytochemical profile of plant parts was well established. The methods for analytical estimations were developed. However, there is paucity of systematic compilation of scientifically important information about this plant. In the present review we have systematically reviewed and compiled information of pharmacognostic, ethnopharmacology, phytochemistry, pharmacology, nutritional aspects, and analytical methods. This review will enrich knowledge leading the way into the discovery of new therapeutic agents with improved and intriguing pharmacological properties.
\end{abstract}

\section{Introduction}

The Indian Ayurvedic plant (kewda) Pandanus odoratissimus Lam. belonging to the family Pandanaceae (Figure 1) [1]. The overall Pandanus genus contains about 600 species distributed mainly in subtropical and tropical regions; there are around 30 to 40 species of Pandanus in India. It is widely distributed in India over coastal districts of Orissa (especially in Ganjam), Andhra Pradesh, Tamil Nadu, and to some extent in parts of Uttar Pradesh [2]. P. odoratissimus is said to be a restore health, strength, or well-being, promoting a feeling of well-being in tropical climates. Ayurvedic science has found the medicinal action of essential oil yielded by the screw pine's highly scented flowers to be useful in headaches, earaches and as a liniment for rheumatic pains. It may be chewed as a breath sweetener or used as a preservative in rice made foods. Pandanus has antiviral, antiallergy, antiplatelet, anti-inflammatory, antioxidant, and anticancer action $[3,4]$. $P$. odoratissimus naturally occurs in high water marking the very edge of the sea and near coastal forests in Southeast Asia, including the Philippines and Indonesia, extending eastward through Papua New Guinea and northern Australia, and throughout the pacific ocean beaches, including Melanesia (Solomon Islands, Vanuatu, New Caledonia, and Fiji), Micronesia (Palau, Northern Marianas, Guam, Federated States of Micronesia, Marshall lands, Kiribati, Tuvalu, and 


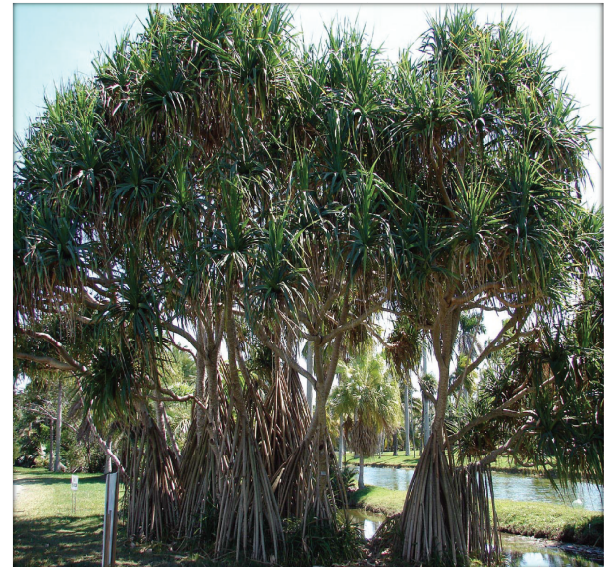

Figure 1: Whole plant; Pandanus odoratissimus Linn. (Family: Pandanaceae).

Nauru), and Polynesia (Wallis and Futuna, Tokelau, Samoa, American Samoa, Tonga, Niue, Cook Islands, French Polynesia, and Hawaii) [4].

\section{Historical Perspectives}

P. odoratissimus Linn. is native to South Asia and India has the tradition of alternative therapies; there are no procedures to test the safety and efficacy of traditional remedies and to standardize their effective cure. For these reasons it is essential to increase our efforts in the area of medicinal plant research and exploit it efficiently for the benefit of humanity.

\section{Habitat}

P. odoratissimus Linn. forest habitat [5] and usually elevations of sea level to $20 \mathrm{~m}$ ( $66 \mathrm{ft}$ ), but can grow at elevations of $600 \mathrm{~m}$ $(1970 \mathrm{ft})$ or higher [6]. Kewda plants are found growing along seashores, banks of rivers, ponds, canals, and so forth [7]. It grows in tropical climate, where it can withstand drought salty spray and strong wind. It propagates readily from seed but it is also propagated from branch cutting for farm or for garden. It grows fairly quickly [8].

Pandanus plant is also called "pandan" and it is native to Asia and even tropical parts of Australia. Pandanus leaves are mostly used in the Southeast Asian cooking (Thomson et al., 2007).

\section{Cultivation and Collection}

Cultivation of $P$. odoratissimus is too little in India, precisely, the Ganjam district in southern Orissa. The plant can be propagated by off sets or division of the suckers. For raising scented types, a fertile, well-drained-soil is preferable. The tree begins to flower 3 to 4 years after planting. The flowering period is rainy season (July-October). The flowers are harvested early in the morning, and the spa dices take a fortnight to mature, depending upon the weather conditions. In India and Burma, the male flowers are valued for their fragrance and some kewda products. Highly prized by Indian perfumer a fully mature tree bears $30-40$ spadices in a year. It is estimated that there are about 30-40 thousand trees in Ganjam district and nearly to a million spa dices are annually used for the production of kewda attar, kewda water, and kewda oil [9].

\section{Pharmacognosy [17]}

See Tables 1 and 2.

\section{Microscopic Characteristics [17]}

6.1. Transverse Section of Leaf (Surface View). Transverse section of leaf showed the presence of single layered upper and lower thin walled epidermal cells, with a moderately thick cuticle, and cells are more or less rectangular. Covering type, unicellular, thick walled, lignified Trichomes, pointed at one end and has a base like that of a hockey stick are emerge from the epidermal layers. Stomata are also seen in the epidermal layer. Mesophyll forms the bulk and is differentiated into thin walled, large, polyhedral, colorless parenchyma with intercellular spaces and 3 to 4 layered, tightly arranged spongy parenchyma (Chlorenchyma). Numerous bundles of acicular rap hides and calcium oxalate crystals as prisms were seen in the parenchymatous cells of mesophyll. Collateral vascular bundles were seen at regular intervals and have protoxylem followed by metaxylem towards upper epidermis and phloem followed by bundle sheath extension (sclerenchyma) towards lower epidermis. The whole vascular bundle is covered by border parenchyma. The TS of the leaf when treated with safranin vascular bundles have stained with pink color and when treated with Sudan red lignified cell wall produced red color.

6.2. Organoleptic Characteristics. Coarsely powdered shade dried leaf of $P$. odoratissimus Linn. is light green in color with characteristic odor and acrid taste.

6.3. Powder Microscopy. It primarily consists of Scalariform and annular xylem vessels; covering type, unicellular, thick walled Trichomes which are lignified and pointed at one end and has a base like that of a hockey stick; paracytic stomata with straight walled epidermal cells surrounding it. Calcium oxalate crystals as prism and acicular raphids scattered in parenchyma.

6.4. Leaf Surface Data. Stomata number and stomata index of leaf of $P$. odoratissimus Linn. were carried out. The value of stomata index of upper epidermis is 23 and lower epidermis is 56 .

6.5. Growth Response. Stem growth is slow to moderate, 2$80 \mathrm{~cm}(0.8-31$ in) per year. Growth and development vary with sex of plant (male or female), variety, and types of planting stock (seedling or branch cutting). For seedling plants, there is a 4-9-year semiprostrate juvenile phase, followed by an erect trunk growth phase of 5-12 years, and then a sexual/ flowering phase of 40 or more years. Male plants are usually more branched, up to about 30 branches (maximum 60), than 
TAble 1: Synonyms of Pandanus odoratissimus.

\begin{tabular}{|c|c|}
\hline Botanical & Pandanus odoratissimus Lam. or Pandanus fascicularis Lamk. and P. tectorius [3] \\
\hline Bengali & Keora, keya, and ketaki \\
\hline English & Umbrella tree, screw pine, and screw tree \\
\hline Gujarati & Kevda, ketak \\
\hline Hawaiian & Hala (P. tectorius) \\
\hline \multirow{2}{*}{ Hindi } & केवड़ा, पुष्पचामर केओड़ा, पांशुका \\
\hline & Kewra, kewda, pushpa-chamar, keora, panshuka \\
\hline Kannada & Kedige, ketake, and tale hu \\
\hline Malayalam & Kaitha, kainari \\
\hline \multirow{2}{*}{ Marathi } & केतकी, केवडा, केगद \\
\hline & Ketaki, kewda, kegad \\
\hline \multirow{3}{*}{ Nepali } & केउरा, केराडा, तारीका, \\
\hline & Keura, kerada, and tarika \\
\hline & Kiora, keura, and kevra \\
\hline Sanskrit & Ketaka \\
\hline \multirow{2}{*}{ Tamil } & தாழை, தாழம்பூ, கேதகை \\
\hline & Tazhai, talai, tazhambu, talambu, and ketakai \\
\hline Telugu & Mogheli, mogil, gedaga, ketaki, and gojjangi \\
\hline \multirow[t]{2}{*}{ Urdu } & كيتكي ,يانشא ,حمبول, ,حبالا ,كيوزٌه \\
\hline & Kiura, kevara, jambala, jambul, panshuka, and ketaki \\
\hline Russian & Pandanus aromatnejshi \\
\hline Japanese & Adan, takonoki \\
\hline
\end{tabular}

females, up to about 15 branches (maximum 30 ). The rate of stem growth varies from very slow to moderate $(2-80 \mathrm{~cm}$ $(0.8-31$ in) per year). Branch diameter is usually reduced by $10-30 \%$ at each branching, and branching ceases when branch diameter is less than about $3.5 \mathrm{~cm}$ (1.4 in) in males and $4.5 \mathrm{~cm}$ (1.8 in) in females. The life span of established Pandanus plants is typically about $50-80$ years (but longevity may be much greater, as long as 100-150 years in some environments). The productive fruiting life of vegetatively propagated plants may be only 20-25 years. Senescence is associated with a gradual decline in branch diameter, leaf size, and number of live branches. Branch death is due to the death of the apical meristem, mainly due to insect damage or breakage. Plants developed from branch cuttings usually grow much faster in earlier years than seedling-derived plants, for example, elongating about $50-80 \mathrm{~cm}$ (20-31 in) per year, and branch from a lower height [6].

\section{Phytochemistry [17]}

7.1. Phytochemical Extracts. Percentage yield and physical characteristics of various extracts of leaf Pandanus are shown in Table 3.

7.2. Chemical Constituents. Phytochemical structures in Pandanus odoratissimus Linn. are included in Table 4.

The principle constituent is the kewda oil, isolated from the inflorescences of Pandanus. The chemical composition of this essential oil, obtained by hydrodistillation of staminate inflorescences of kewda ( $P$. odoratissimus), when subjected to high resolution GC (gas chromatography) and GC-MS (gas chromatography and mass spectrometry) has been shown to yield ether (37.7\%), terpene-4-ol (18.6\%), $\alpha$-terpineol $(8.3 \%)$ and 2-phenylethyl alcohol (7.5\%), benzyl benzoate (11\%), viridine $(8.8 \%)$, and germacrene-B $(8.3 \%)$ along with a small amount of benzyl salicylate, benzyl acetate, benzyl alcohol, and so forth; ethnobotanically kewda oil is used in earache, headache, arthritis, debility, giddiness, laxative, rheumatism, small pox, and spasms. The methanol and aqueous extracts of the leaves of Pandanus were subjected to preliminary phytochemical screening and they were tested for the presence of alkaloids, carbohydrates, proteins, steroids, sterols, phenols, tannins, terpenes, flavonoids, gums and mucilage, saponins, and glycosides [10]. The total phenolic content in the aqueous extract was ranged from 3.5 to $10.8 \% \mathrm{w} / \mathrm{w}$ phenolic which are the largest groups of phytochemicals and have been said to account for most of the antioxidants activity of plant extracts $[21,35]$. Physcion, cirsilineol, n-triacontanol, $\beta$-sitosterol, camphosterol, daucosterol and palmitic acid, and steric acid in rhizomes have been reported [24].

Phytochemicals chemical analysis of the root extracts of P. odoratissimus led to the isolation of phenolic compounds, lignans type compounds, and some benzofuran derivative. $\alpha$-terpineol, $\beta$-carotene, $\beta$-sitosterol, benzyl-benzoate, pinoresinol, germacrene-B, vitamin $C$, viridine. tangeterine, 5,8-hydroxy-7 methoxy-flavone, vanidine. Among them, 
TABLE 2: Plant monograph.

Biogeography and ecology

Plant name: Pandanus odoratissimus Linn

Kingdom: Plantae-plants

Subkingdom: Tracheobionta

Family: Pandanaceae

Genus: Pandanus L. F.

Species: Pandanus odoratissimus

$[9,10]$

Botanical description

Flowers

Male flowers

A large, terminal, pendulous, compound, leafy, raceme, the leaves of which are white, linear-oblong, pointed, and concave; in the axill of each, there is a single thyrsus of simple, small racemes, of long-pointed, depending anthers; they are not sessile, but raised from the rachis of the raceme by tapering filaments.

Female flowers

A different plant, terminal and solitary, having no other calyx or corol than the termination of the three rows of leaves forming three imbricate fascicles of white floral leaves, like those of the male raceme, which stand at equal distances, round the base of the young fruit. Germs numerous, collected in firm wedge-shape angular bundles from six to ten or more (these form the compound germs of the future drupes), closely impacted round the receptacle.

Fruit

compound; oval, from five to eight inches in diameter, and from six to ten long, weighing from four to eight pounds; rough, rich orange-colour, composed of drupes numerous, wedge-shape, angular; when ripe, their large or exterior ends are detached from one another and covered with a firm, deeper orange-colored skin; apices flat, consisting of as many angular, somewhat convex, tubercles, as there are cells in the drupe, each crowned with the withered stigma, internally; the exterior half of these drupes (next the apex) consists of dry spongy cavities, their lower part next to the core or common receptacle is yellow, consisting of a rich-looking, yellow pulp, intermixed with strong fibres; here the nut is lodged.

Nut

Each drupe compound, top-shape, exceedingly hard, angular, containing as many cells as there are divisions on the apex of the drupe; each cell is perforated above and below.

Seed

Single, oblong, smooth, adhering lengthways to a small fascicle of strong, white fibers, which pass through the perforation of the cell. By far the greatest numbers of these cells are barren. It is a native of the warmer parts of Asia. All soils and situations seem to suit it equally well; it flowers chiefly during the rainy season. It grows readily from branches, whence it is rare to find the full grown ripe fruit. The male is by far the most common, a circumstance merely accidental; for I have seen some old extensive hedges entirely female, owing to their having been originally a female plant or plants nearest to these places.

Trunk

A plant may be found with a single, pretty v erect one, often feet in height, and a ramous round head; but this is seldom, for it is generally in form of a very large, ramous, spreading bush. From the stems or larger branches issue large carrot-shape, obtuse-pointed, roots, descending till they come to the ground, into which they enter and then divide. The substance of the most solid wood is something like that of a cabbage stem and by age acquires a woody hardness on the outside.

Leaves

confluent, stem-clasping, closely imbricated in three spiral rows, round the extremities of the branches, bowing; from three to five feet long, tapering to a very long fine triangular point, very smooth and glossy, margins and back armed with very fine sharp spines; those on the margins point forward, those of the back point sometimes one way, sometimes the other style.

Stigma

Single, oval, grooved lengthwise, yellow, affixed to the outside of a two-lipped umbilicus on the apex of the germ. It is the tender white leaves of the flowers (chiefly those of the male) that yield that most delightful fragrance, for which they are so universally and deservedly esteemed; and of all the perfumes that I know, it is by far the richest and most powerful. The lower yellow pulpy part of the drupe is sometimes eaten by the natives in times of scarcity and famine, and the tender white base of the leaves are also eaten raw or boiled, at such melancholy times. The taste of the pulpy part of the drupe is to me very disagreeable. The fusiform roots, already mentioned, are composed of tough fibers; they are so soft and spongy as to serve the natives for corks; the leaves also are composed of longitudinal, tough, useful fibers. 
TABLE 2: Continued.

Root

The subterranean root system is concentrated in the surface soil layers. Apart from the aerial and prop roots, the tree's root system is unlikely to interfere with maintenance or recreational activities, lawns, or structures such as sidewalks or foundations [1].

TABle 3: Phytochemical extracts and their characteristics.

\begin{tabular}{|c|c|c|c|c|}
\hline Extracts & $\%$ dry wt. in g. & Colour & Odour & Consistency \\
\hline Alcoholic & 11.48 & Blackish green & Own characteristic & Sticky \\
\hline \multicolumn{5}{|c|}{ Successive extraction } \\
\hline Petroleum Ether $\left(40-60^{\circ} \mathrm{C}\right)$ & 2.08 & Dark brown & Own characteristic & Waxy \\
\hline Chloroform & 2.66 & Dark Green & Own characteristic & Powder \\
\hline Ethyl acetate & 1.91 & Brownish yellow & Own characteristic & Sticky \\
\hline n-Butanol & 2.11 & Brown & Own characteristic & Sticky \\
\hline Methanol & 8.24 & Reddish Brown & Own characteristic & Sticky \\
\hline
\end{tabular}

pinoresinol and 3,4-bis(4-hydroxy-3-methoxybenzyl)tetrahydrofuran showed strong antioxidative activities when BHA was used as a standard in the thiocyanate method. The new compounds were identified as 4-hydroxy-3- $\left(2^{\prime}, 3^{\prime}\right.$-dihydroxy$3^{\prime}$-methylbutyl)-benzoic acid methyl ester and 3-hydroxy2-isopropenyl-dihydro-benzofuran-5-carboxylic acid methyl ester, by spectroscopic analysis.

The methanol extract of $P$. odoratissimus was subjected to column chromatography to isolate a total of 15 compounds. Steroids, including phytosteroid mixtures; a-spin sterol and stigmast-7-en-3b-ol mixture; a-spinasterol caproate; stigmast-4-en-6b-ol-3-one and three phenolic compounds; vanillin (1); 2 (E)-3-(3'-methoxy-4-hydroxyphenyl)-prop-2-enal (2); 4-hydroxy-3-(2', $3^{\prime}$-dihydroxy-3' -methyl-butyl)-benzoic acid methyl ester (3) and a new benzofuran derivative, 3-hydroxy-2-isopropenyl-dihydrobenzofuran-5-carboxylic acid methyl ester (4); plus six lignans; eudesmin (5); kobusin (6); pinoresinol (7); epipinoresinol (8); de-4'-O-methyleudesmin (9); and 3,4-bis(4-hydroxy-3-methoxy-benzyl)-tetrahydrofuran (10), were isolated and identified by comparing their data with authentic materials on the basis of their mass, UV, IR, and $1 \mathrm{H}$ and 13C NMR spectra [36]. And total synthesis of four Pandanus alkaloid: Pandamarilactonine-A, and $\mathrm{B}$, and their chemical precursors non Pandamarilactonine-A and $B$ [37].

\section{Nutritional Aspects and Staple Food (Figure 2 and Table 5)}

8.1. Staple Food. Pandanus fruits are a staple food in parts of Micronesia including the Marshall Islands, Federated States of Micronesia, and Kiribati providing up to $50 \%$ of energy intake $[11,15]$. They are also widely consumed on Tokelau and Tuvalu [11]. In some places the consumption of Pandanus has decreased in recent decades due to the availability of imported foods; for example, Pandanus was formerly a major staple food in Nauru [38]. In Micronesia adults may commonly consume 20 fresh keys or about $1 \mathrm{~kg}(2.2 \mathrm{lb})$ of fruit per day. The fruit pulp is preserved in several different ways. A paste, which is compared to dates in taste, texture, and appearance, is made by boiling and baking the keys, followed by extracting, processing, and drying the pulp. Cultivars with large amounts of pulp are preferred, and the taste differs among cultivars. On average, $100 \mathrm{~g}$ Pandanus paste provides 321 kilocalories, $2.2 \mathrm{~g}$ protein, $134 \mathrm{mg}$ calcium, $108 \mathrm{mg}$ phosphorus, $5.7 \mathrm{mg}$ iron, $0.04 \mathrm{mg}$ thiamin, $2 \mathrm{mg}$ vitamin $\mathrm{C}$ [1416], and from 390 to $724 \mu \mathrm{g} / 100 \mathrm{~g}$ beta-carotene (a carotenoid that is a precursor to vitamin A), depending on variety and coloration $[12,13]$. Fresh Pandanus is an important source of vitamin C. Preserved Pandanus pulp mixed with coconut cream makes a tasty, sweet food item. Pandanus can also be made into flour that is consumed in different ways, usually prepared as a drink (Figure 2).

8.2. Fruit. The keys of selected edible cultivated varieties, those with low amounts of calcium oxalate crystals, are consume draw or cooked. Juice and jam may also be prepared from the fruit. In parts of Micronesia, chewing Pandanus keys is usually done outside of meal times and is a pleasurable, highly social activity. Adults may typically consume 20-50 keys daily during the main fruiting seasons [11].

A $100 \mathrm{~g}$ portion of edible pericarp is mainly comprised of water $(80 \mathrm{~g})$ and carbohydrates $(17 \mathrm{~g})$. There are also significant levels of beta-carotene (19 to $19,000 \mu \mathrm{g}$ ) and vitamin C (5 mg), and small amounts of protein $(1.3 \mathrm{mg})$, fat $(0.7 \mathrm{mg})$, and fiber $(3.5 \mathrm{~g})$ [11-13]. The edible flesh of deeper yellowand orange-colored varieties contain higher provitamin A carotenoid levels. The fruit of these varieties has considerable potential for alleviating vitamin A deficiency in Micronesia [11]. As carotenoid-rich food may protect against diabetes, heart disease, and cancer, the consumption of Pandanus may also alleviate these serious emerging problems of the Pacific. Pandanus fruit is also a useful source of vitamin C (ascorbic acid), thiamine, riboflavin, and niacin (vitamin B-3) $[14,15]$. The fruit of wild forms of Pandanus contains oxalate crystals that irritate the mouth unless broken down by cooking. 
TABle 4: Phytochemical structures in Pandanus.

Chemical name

Norpandamarilactonine-A

Pandamarilacton-32

Norpandamarilactonine-A

Norpandamarilactonine-B

$\longrightarrow \mathrm{H}_{3} \mathrm{C}$
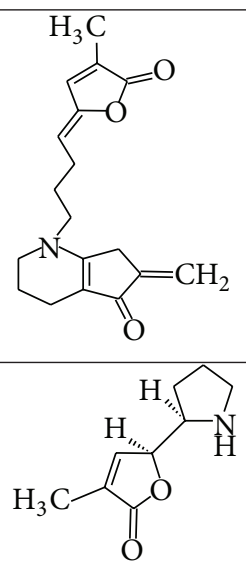

$\left(\mathrm{C}_{18} \mathrm{H}_{25} \mathrm{NO}_{4}\right)$

Pandamarilactonine-A
$\left(\mathrm{C}_{18} \mathrm{H}_{25} \mathrm{NO}_{4}\right)$

Pandamarilactonine-C, -D

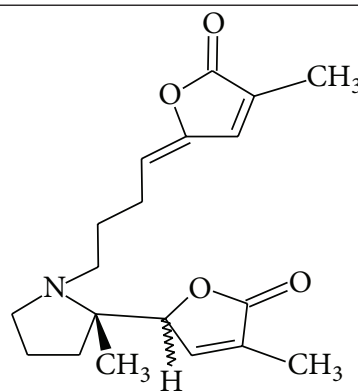


TABLE 4: Continued.

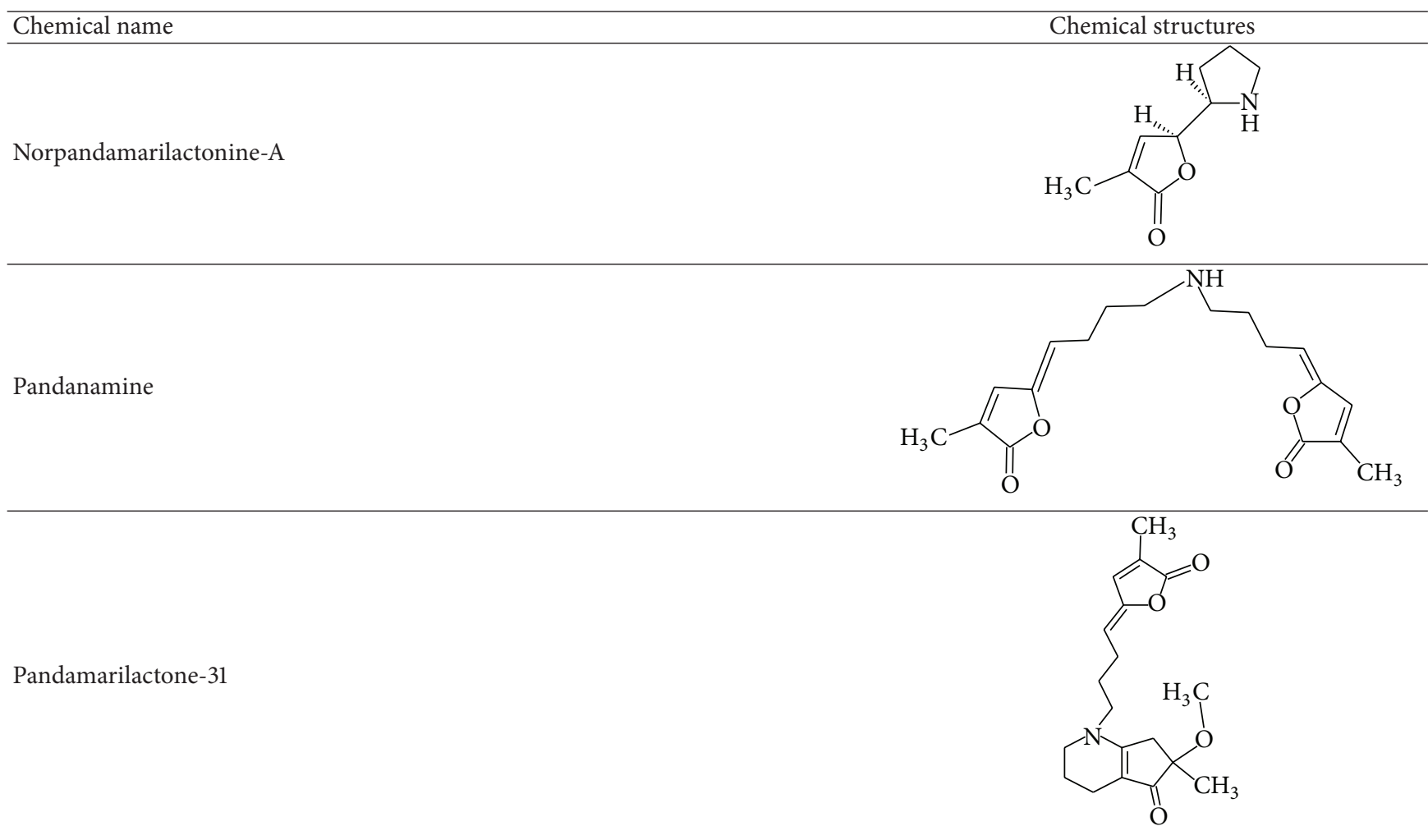
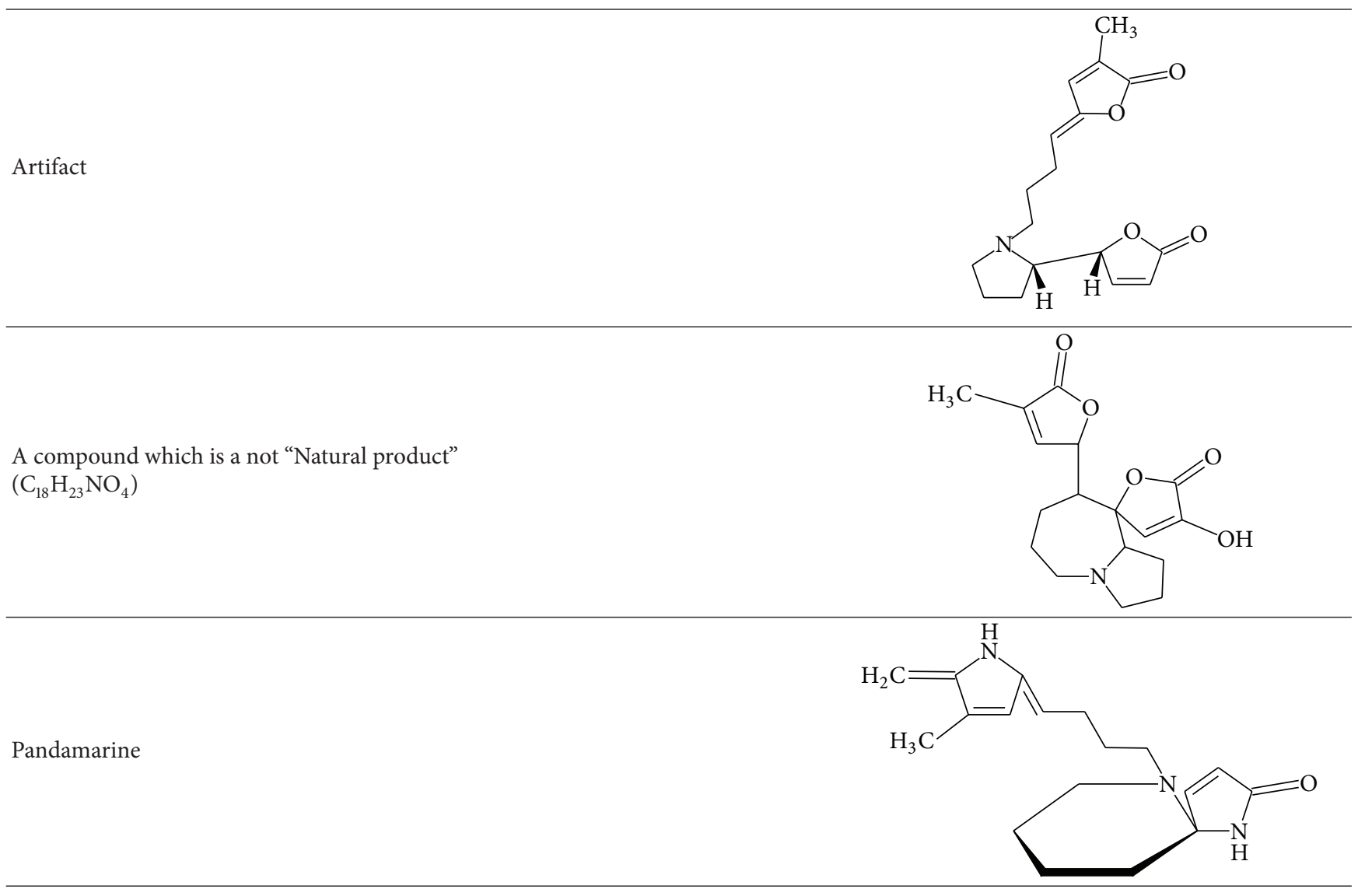
TABLE 4: Continued.

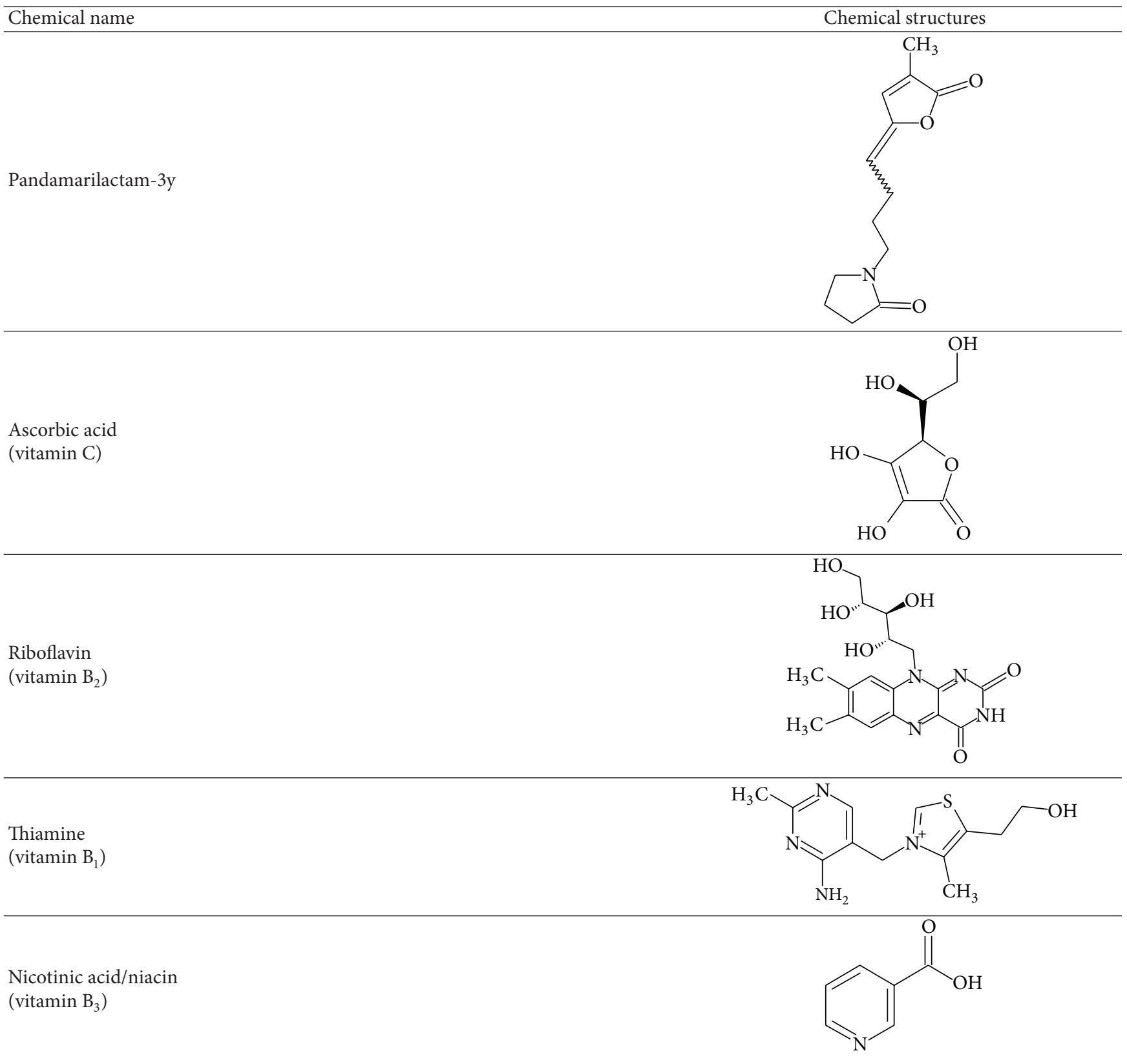

The ripe fruit of wild forms may be consumed following cooking and straining the pericarp, but they are not especially palatable or sweet (Table 5).

8.3. Nut/Seed. The small seeds of a few varieties of $P$. tectorius are eaten. A similar species, $P$. dubius, has larger seeds that are eaten.

8.4. Beverage/Drink/Tea. Juice pressed from the fruits is sweet and slightly acid with a pungent flavor [15]. It is being produced commercially in the Marshall Islands.

\section{Traditional Uses and Products}

Different parts of the Pandanus plant are used to provide a myriad of end products throughout the Pacific Islands, especially on atolls. The trunk and large branches are commonly used for building materials in house construction and for ladders. They are also used to make headrests/hard pillows, vases, and fish traps, as sources of glue or caulking for canoes, to extract cream from grated coconuts, and as an aid in making string. Trunks and branches may be burnt for fuel wood or used to make compost. Prop or aerial roots are used in fabrication of house walls and as supports, basket handles, 

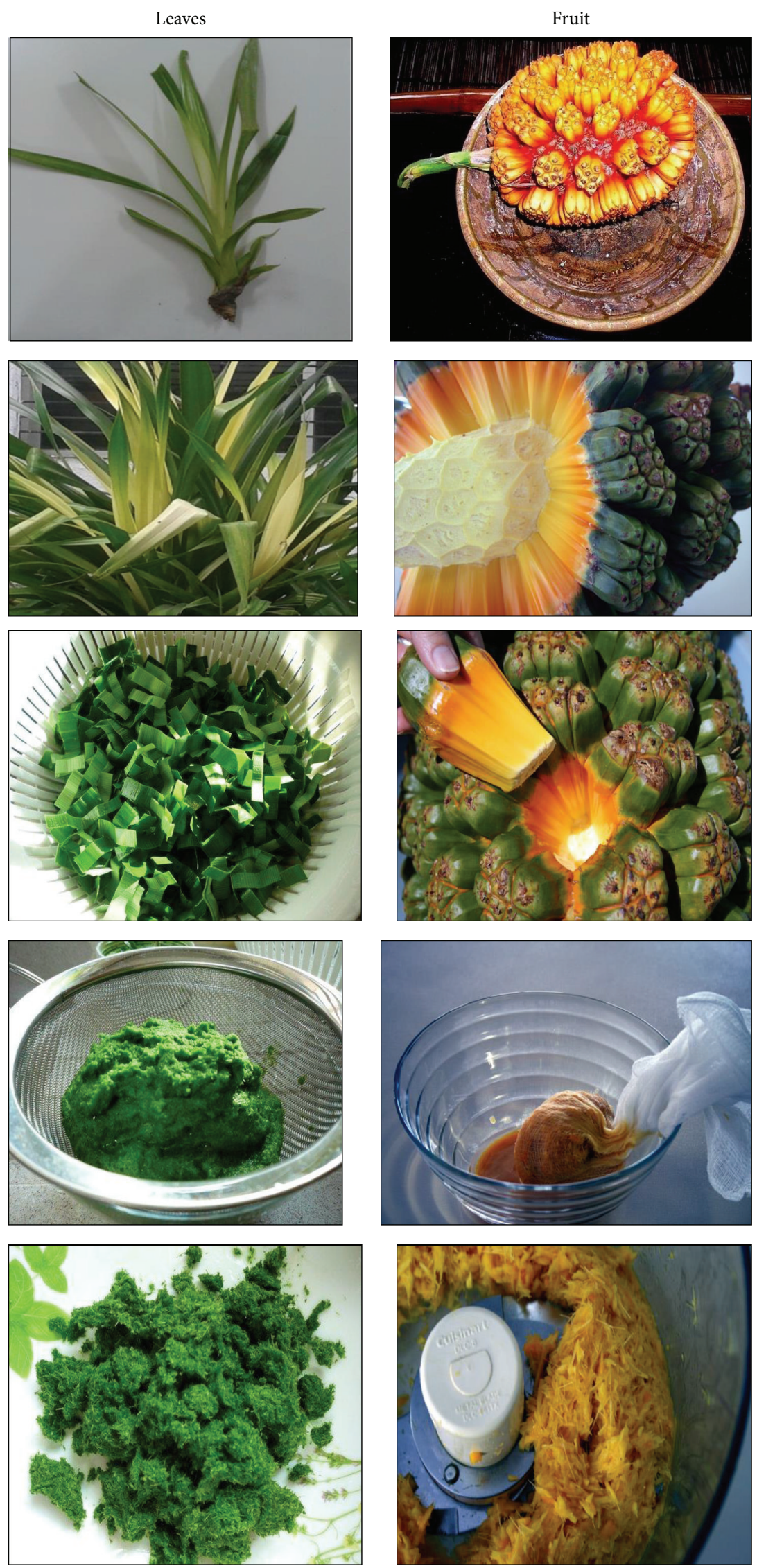

FIgURE 2: Continued. 

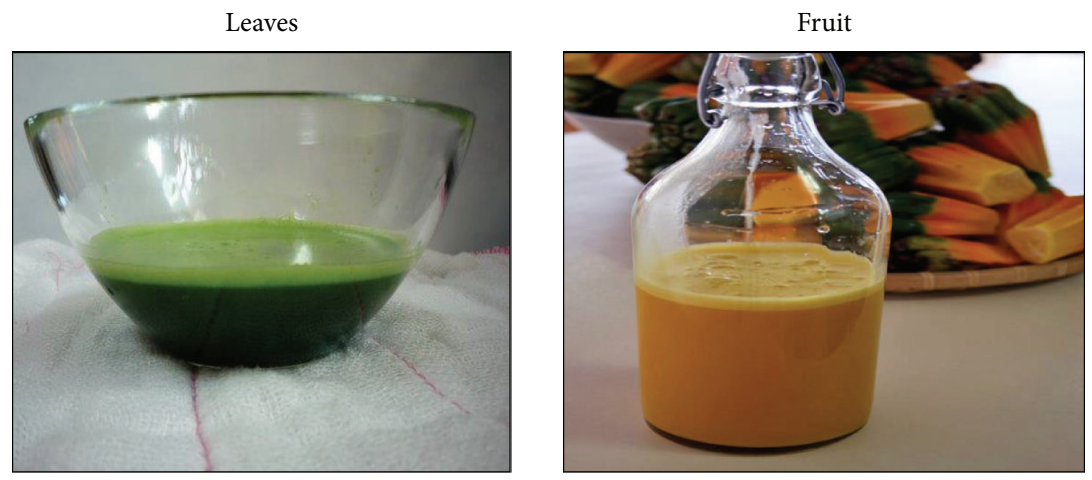

FIgURE 2: Nutritional aspects and staple food of Pandanus.

TABle 5: Nutritional aspects of Pandanus or screw pines.

\begin{tabular}{|c|c|c|c|}
\hline & Edible pericarp* & Pandanus paste & References \\
\hline \multirow{8}{*}{$\begin{array}{l}\text { Per } 100 \mathrm{~g} \text { of it Contents of } \\
\text { pandan }\end{array}$} & 228 kilocalories, & 321 kilocalories, & \multirow{7}{*}{$\begin{array}{l}([11-13])^{*} \\
([14-16])^{\#}\end{array}$} \\
\hline & water $(80 \mathrm{~g})$ & $2.2 \mathrm{~g}$ protein, & \\
\hline & carbohydrates (17 g), & $134 \mathrm{mg}$ calcium, & \\
\hline & beta-carotene (19 to $19,000 \mu \mathrm{g})$ & 108 mg phosphorus, & \\
\hline & vitamin C (5 mg), & $5.7 \mathrm{mg}$ iron, & \\
\hline & protein (1.3 mg), & $0.04 \mathrm{mg}$ thiamin, & \\
\hline & fat $(0.7 \mathrm{mg})$, & 2 mg vitamin $C$, & \\
\hline & fiber (3.5 g) & $\begin{array}{l}390 \text { to } 724 \mu \text { g beta-carotene } \\
\text { (vitamin A) }\end{array}$ & {$[12,13]$} \\
\hline Pandanus pulp & $\begin{array}{l}\text { Usually prepared as a drink; } \\
\text { mixed with coconut cream mal }\end{array}$ & asty, sweet food item & {$[12,13]$} \\
\hline \multirow{2}{*}{$\begin{array}{l}\text { Flesh of deeper yellow- and } \\
\text { orange-colored pandan } \\
\text { keys }\end{array}$} & \multicolumn{2}{|c|}{$\begin{array}{l}\text { Adults may consume } 20-50 \text { keys typically; highly } \\
\text { pleasurable, } 50 \% \text { of energy intake }\end{array}$} & {$[11]$} \\
\hline & \multicolumn{2}{|c|}{$\begin{array}{l}\text { As carotenoid (provitamin-A) rich food may protect against } \\
\text { diabetes, heart disease, and cancer and alleviate these serious } \\
\text { emerging problems }\end{array}$} & {$[11]$} \\
\hline \multirow[t]{2}{*}{ Fresh Pandanus fruit } & \multicolumn{2}{|c|}{$\begin{array}{l}\text { Vitamin C (ascorbic acid), thiamine, riboflavin, and niacin } \\
\text { (vitamin B-3) }\end{array}$} & {$[14,15]$} \\
\hline & \multicolumn{2}{|l|}{$\begin{array}{l}\text { Juice and jam } \\
\text { In parts of Micronesia, chewing }\end{array}$} & {$[11,15]$} \\
\hline
\end{tabular}

paintbrushes, and skipping ropes. They are also used to produce dyes and in production of traditional medicines. The leaves of selected varieties are treated by soaking in the sea and/or boiling or heating and dying and are then used to make mats, baskets (for ladies and to keep valuables), hats, fans, pillows, canoe sails (formerly), toys, and other plaited wares. The leaves are also used for thatching (both walls and roofs) and for making compost, including special composting baskets woven around the base of giant swamp taro, cigarette wrappers, balls for children's games, and ornaments. They are used for traditional medicines and as a cooking aid in some recipes. The young leaves are used in traditional medicine and for lancing boils, making fans, decoration, and pig feed. Throughout the atoll island countries of the central/northern Pacific, the fleshy keys of the fruits of many traditionally selected, named, and cultivated varieties are consumed fresh or made into various preserved foods. The fruits are also consumed in Solomon Islands and Papua New Guinea. In Polynesia the fragrant, ornamental fruits of different varieties are strung into leis or garlands and used to make perfume. The fibrous, dried, mature drupes are used as paint brushes for painting tapa, for fuel, and for compost, and as fishing line floats. In Kiribati the fruit may also be used as bait for catching lobster. The fragrant male flowers are used to scent coconut oil, perfume tapa cloth, and make garlands.

9.1. Animal Fodder. Leaves, particularly young leaves, are recorded as providing fodder for domestic animals such as pigs and horses.

9.2. Masticant/Stimulant. Male Pandanus flowers have been credited with aphrodisiac properties in Marshall Islands. 
9.3. Beautiful/Fragrant Flowers. The highly fragrant male flowers are widely used for decoration.

9.4. Timber. The stems are used in house construction and also for making ladders, especially on atoll islands. Male trees have hard, solid trunks with a yellow interior containing dark brown fiber bundles. The male wood is very strong, but brittle, meaning that it can suddenly break under a heavy load. It is also a difficult wood to split. Trunks of female trees are hard on the outside, but soft, pithy, or juicy in the interior [39]. Slats made from the clean, dried aerial/prop roots are used for walls of houses and food cupboards.

9.5. Fuel Wood. In the northern Pacific, the discarded, dried keys are highly prized as fuel wood for cooking because they are slow burning and therefore preferred for barbecues. The trunk and branches are occasionally used as fuel wood where other fuel wood is scarce, such as on atolls.

9.6. Craft Wood/Tools. The wood has many craft uses, such as headrests/pillows, vases, and as an aid for string making and extracting coconut cream. It was formerly used to make weapons (lances and batons). When the flesh is removed from the inner end of a dried key, fibrous bristles are exposed. The bristle end can be used as a brush for decorating tapa, with the hard, woody outer end acting as a handle. Fish traps are made out of the aerial roots in Kiribati.

9.7. Canoe/Boat/Raft Making. The trunk of one variety in the Marshall Islands is used to make the masts of traditional canoes. In Hawaii Pandanus leaves were the traditionally main material for making canoes ails [40].

9.8. Fiber/Weaving/Clothing. In many Pacific countries Pandanus leaves are used to weave traditional items of attire, including mats for wearing around the waist in Tonga, as well as hats and various types of baskets.

9.9. Rope/Cordage/String. The roots are made into skipping ropes and basket handles. String or cordage is made from the cleaned and dried prop roots.

9.10. Wrapping/Parcelization. The leaves are used to wrap tobacco/cigarettes in Micronesia.

9.11. Thatch/Roofing/Mats. Pandanus leaves are used to weave traditional floor mats in many Pacific countries, as well as in the construction of traditional houses (thatch for walls and roofing). A roof made from Pandanus leaves is said to last about 15 years, while one of coconut leaves may last only 3 years [39].

9.12. Resin/Gum/Glue/Latex. The trunk is a source of glue or caulking for canoes.
9.13. Body Ornamentation/Garlands. Leaves, often neatly cut, fragrant fruits, and flowers are used in making garlands or leis.

9.14. Ceremonial/Religious Importance. Pandanus is sometimes considered to have supernatural and magical properties in parts of Micronesia and Hawaii. In Kiribati it may be used as a ceremonial food, while in Indonesia the male flowers are used in ceremonies.

9.15. Other Uses. In Kiribati and the Marshall Islands the leaves are formed into a ball for use in a kicking game. The trunks of female trees are hard on the outside but soft or juicy in the interior. The female trunks have been used as water pipes after removing the soft interior [39].

In the Philippines, pandan leaves are being cooked along with rice to incorporate the flavor and smell to it. As can be observed, the uses of the pandan tree are not limited to cooking uses. Its leaves and roots are found to have medicinal benefits. Such parts of the plant have been found to have essential oils, tannin, alkaloids, and glycosides, which are the reasons for the effective treatment of various health concerns. It functions as a pain reliever, mostly for headaches and pain caused by arthritis, and even hangover. It can also be used as antiseptic and antibacterial, which makes it ideal for healing wounds.

In the same manner, a preparation derived from the bark of this plant may be used to address skin problems. Many people have also discovered that it is an effective remedy for cough. In India, pandan leaves are being used to treat skin disorders like leprosy and smallpox. The bitter tasting quality of the leaves makes it ideal for health problems which include, but are not limited to, diabetes fever, ulcer, and wounds.

In Hawaii, pandan flowers are being chewed by mothers who later give the chewed flowers to their children, as laxative. The juice extracted from pounded roots of this tree are issued and mixed with other ingredients to ease chest pains. Also, it is used as tonic for women who have just given birth and who are still in weak states. Pandan flowers have also been traced with characteristics that function as aphrodisiac. Pandan also manifests anticancer activities, and that is why modern researches in the United States have subjected this plant for further experiments and investigation [41].

Sometimes it is oven dried and kept in bottles for preservation until it is used. This product is mostly available in western countries in dried form. Other than that there are many recipes. To impart its aroma into chicken, pieces of marinated chicken are enclosed in a clever wrapping of "Pandanus" leaves and grilled or deep fried. The leaves which are pounded and strained (or blended with a little water) impart flavor and color into cakes and sweets. This flavor is a delicacy to Asians and is as important as vanilla to Westerners. These leaves are used to make small containers for sweets, jelly, and puddings. Some people wrap their hot foods using these leaves as they produce aroma when the food is still warm. These plants can be easily propagated by side shoot cuttings taken from the base of the plant. The higher the maturity of the cutting is, the easier the establishment is [41]. 
TABLE 6: Ethnomedicinal uses of $P$. odoratissimus.

\begin{tabular}{ll}
\hline Plant parts & Medicinal uses \\
\hline \multirow{2}{*}{ Leaves } & $\begin{array}{l}\text { Leprosy, aphrodisiac, scabies, anxiety and heart disease, leucoderma, tumors, leprosy, } \\
\text { antiepileptic, anticonvulsions, and skin disease }\end{array}$ \\
Flower & Female rats fertility regulator [17] \\
Root & Headaches, earaches, antispasmodic, and aphrodisiac [17] \\
Oil & Antidiabetics, antidote, abortifacient; skin diseases, leprosy, scabies, and syphilis [18] \\
Fruit & Rheumatoid arthritis, skin disease, earache, headache, arthritis, debility, depurative, giddiness, \\
& laxative, leprosy, small Pandanus odoratissimus, and spasms \\
\hline
\end{tabular}

Supercritical carbon dioxide (SC-CO2) and Soxhlet extraction using hexane as solvent were used to extract 2acetyl-1-pyrroline (2-AP) from pandan leaves. The effect of different extraction pretreatments such as particle size and drying on the extraction yield and concentration of 2-AP were investigated. The identification and quantification of 2-AP were carried out by gas chromatography-mass spectrometry and gas chromatography-flame ionization detector, respectively. This work aims to provide an understanding of the phenomena that occur during cooking and storage, typically on the changes of 2-AP absorption when cooking rice grains with pandan leaves. The parameters investigated were cooking method of excess and optimal water conditions. Even though low in yield and the fact that the 2-AP concentration was obtained from supercritical carbon dioxide extraction, the extracts were pure without any contamination. The grinding and freeze-drying method revealed the best pretreatments for supercritical extraction. The absorption of 2AP during the cooking of rice grains did not smoothly increase with time. This unexpected result indicated that the phenomena occurring during cooking are quite complex. This work also quantified the potential of pandan leaves to enhance the flavour of cooked rice, particularly under excess water conditions. Storage for $15 \mathrm{~min}$ at $24.0 \pm 1.0^{\circ} \mathrm{C}$ is considered as the optimum time for obtaining cooked rice with a high quality of flavor [42].

\section{Ethnomedicinal Uses}

Pandanus is a very important medicinal plant, with certain varieties sometimes preferred for particular treatments. Leaves, especially the basal white section of young leaves, and roots are used. In Kiribati, Pandanus leaves are used in treatments for cold/flu, hepatitis, dysuria, asthma, boils, and cancer, while the roots are used in a decoction to treat hemorrhoids. In Hawaii the main parts used in making traditional medicines are the fruits, male flowers, and aerial roots [40]. These are used individually or in combination with other ingredients to treat a wide range of illnesses, including digestive and respiratory disorders. The root is used in Palauto to make a drink that alleviates stomach cramps, and the leaves are used to alleviate vomiting [43]. The root is also known for its use in traditional medicine in Pohnpei for STD'S, namely, syphilis $[17,18,44]$ (Table 6).

\section{Pharmacology}

A summary of reported pharmacological activity of Pandanus odoratissimus is shown in Table 7.

\subsection{Acute Oral Toxicity Study}

11.1.1. In Mice. Selected animals both female and male mice administered with the extract at a dose of $2000 \mathrm{mg} / \mathrm{kg}$ showed no toxicity during the experimentation period. In both sexes of mice, body weight gain of treatment rats was not changed significantly relative to that of control. While conducting the toxicity studies, animals were observed continuously for any general behavioral changes. A significant reduction in spontaneous locomotors motility, drowsiness, and remarkably quiet behaviors were observed. Thus, the extract of $P$. odoratissimus with an $\mathrm{LD}_{50}>2000 \mathrm{mg} / \mathrm{kg}$ is considered nontoxic through acute exposure in mice $[8,24]$.

11.1.2. In Rats. Administration of hydroethanol leaf extract of $P$. odoratissimus Linn. $2000 \mathrm{mg} / \mathrm{kg} / \mathrm{p}$.o. dose did not show behavioral change (Erwin's test) at continuous observation for $4 \mathrm{~h}$ and intermittent of $48 \mathrm{~h}$. No mortality was observed during total observation period of 14 days. $\mathrm{LD}_{50}$ was found to be more than $2000 \mathrm{mg} / \mathrm{kg}$ calculated by AOT425 statpgm (Version: 1.0), Acute Oral Toxicity (OECD Test Guideline 425) Statistical Program (AOT Report) on the basis of AOT425 report 200 and $300 \mathrm{mg} / \mathrm{kg}$ doses were selected for evaluating effect as antiepileptic and for fertility effect of $P$. odoratissimus Linn. [19].

11.2. Antioxidant Activity. The antioxidant activity of methanolic extracts of leaves of $P$. odoratissimus by four different in vitro models. The lipid peroxidation was assayed by estimating the thiobarbituric acid reactive substances (TBARS) in normal rat by liver homogenates. The reduced glutathione (GSH) was assayed in liver homogenates of different concentrations of Pandanus methanol extract using the method of Ellman et al. The nitric oxide (NO) scavenging activity and 1,1-diphenyl, 2-picryl hydrazyl (DPPH) radical scavenging activity were measured using the methods of Sreejayan et al. and Shimada et al., respectively, using spectrophotometer. Vitamin E and normal saline were used as reference standard and control for all four by in vitro type of bioassy methods 
TABLE 7: A summary of reported pharmacological activity of $P$. odoratissimus [17].

\begin{tabular}{|c|c|c|}
\hline Species/method used & Property & Source \\
\hline \multirow{12}{*}{ Wistar rats } & Antiepileptic and anticonversant & {$[19]$} \\
\hline & Antioxidant & {$[20,21]$} \\
\hline & Anti-inflammatory & {$[22]$} \\
\hline & Acute anti-inflammatory & {$[10]$} \\
\hline & Analgesic & {$[23]$} \\
\hline & Antidiabetic & {$[24-26]$} \\
\hline & Diuretic activity & {$[25]$} \\
\hline & Hepatotoxic & {$[27]$} \\
\hline & Hepatoprotective \& hepatocurative activity & {$[27,28]$} \\
\hline & Fertility enhancer and regulation activity, in female rats & {$[17]$} \\
\hline & Sex stimulant activity, in male rats & \\
\hline & Aphrodisiac & {$[17]$} \\
\hline \multirow{2}{*}{ Swiss albino mice } & Antidiabetic & {$[24-26]$} \\
\hline & CNS depressant activity & {$[8]$} \\
\hline $\begin{array}{l}\text { Bacillus subtilis, } \\
\text { Escherichia coli, } \\
\text { Staphylococcus aureus, and } \\
\text { Candida albicans }\end{array}$ & Antimicrobial activity & {$[29-31]$} \\
\hline $\begin{array}{l}\text { Aspergillus flavus, } \\
\text { Microsporum nanum, } \\
\text { Epidermophyton floccosum, } \\
\text { Trichophyton tonsurans, } \\
\text { Mentagrophytes, and } \\
\text { Trichophyton } \\
\text { verrucosum }\end{array}$ & Antifungal activity & {$[32]$} \\
\hline $\begin{array}{l}\text { Human viruses, } \\
\text { herpes simplex, } \\
\text { type I (HSV-1), and influenza } \\
\text { virus (H1N1) }\end{array}$ & Antiviral activity & {$[33]$} \\
\hline Inhibition of hydroxyl radicals & Free scavenging activity & {$[21]$} \\
\hline $\begin{array}{l}\text { Adult Indian earthworms, } \\
\text { Pheretima posthuma }\end{array}$ & Anthelmintic activity & {$[34]$} \\
\hline
\end{tabular}

antioxidant measurement assays. The results showed significant antioxidant activity of Pandanus methanol extract in all four by in vitro type of bioassay methods used in this study and the $\mathrm{IC}_{50}$ (the half maximal inhibitory concentration of an inhibitor that is required for $50 \%$ inhibition of antioxidant activity) of plant extract was comparable to that of vitamin $\mathrm{E}$, the reference standard compound used in this study. It is concluded that the methanolic extract of leaves of $P$. odoratissimus has significant antioxidant activity [20, 21].

11.3. Anti-Inflammatory Activity. The anti-inflammatory activity was estimated by carrageenan-induced acute and formalin-induced chronic paw edema models in rats. The methanolic extract of $P$. odoratissimus was given in the doses of 25,25 , and $100 \mathrm{mg} / \mathrm{kg}^{-1}$. The plant extract at the dose of $100 \mathrm{mg} \mathrm{kg}^{-1}$ showed significant anti-inflammatory activity at $3 \mathrm{~h}$ observation where, it caused increase in inhibition of paw edema by carrageenan-induced acute $(68 \%)$ and the formalin-induced chronic (64.2\%) paw edema models with standard drug diclofenac sodium in rats [22].

11.4. Acute Anti-Inflammatory Activity. Plants are widely used in the various traditional systems of medicine like Ayurveda, Siddha, and Unani for their analgesic, anti-inflammatory, and antipyretic activity. P. odoratissimus (kewda) has been used in rheumatic fever, rheumatism, and rheumatoid arthritis. The chemical composition of this essential oil, obtained by hydrodistillation of staminate inflorescences of kewda includes more than sixty components. The major components of the hydrodistilled kewda oil are 2-phenyl ethyl methyl ether terpene-4-ol, $\alpha$-terpineol, 2-phenyl ethyl alcohol benzyl benzoate, and so forth. Kewda oil is traditionally used in earache, headache, arthritis, debility, giddiness, laxative, and rheumatism. Both methanolic and hydroalcoholic extracts were tested in rodent models by carrageenan-induced paw edema, albumin induced plantar edema, acetic acid induced 
vascular permeability, and castor induced diarrhoea. In all these animal models both extracts have shown significant anti-inflammatory activity [10].

11.5. Analgesic Activity. Analgesic activity of aqueous extract of $P$. fascicularis Lam. at doses ( 400 and $800 \mathrm{mg} / \mathrm{kg}$ ) by using hot plate models, tail-flick method in rats. and the writhing model of mouse and compared with the analgesic action of codeine and aspirin. Pandanus aqueous extract revealed significant analgesic activity by both central $(P<0.001)$ and peripheral $(P<0.001)$ mechanisms in this study, which is comparable to that of codeine and aspirin, and this favors the use of Pandanus aqueous extract in rheumatism and rheumatoid arthritis in traditional medicine [23].

11.6. Antidiabetic Activity. The roots of $P$. odoratissimus aqueous extract were tested for its effect on blood glucose levels in normal and diabetic rats. Hypoglycemia was observed in basal condition when tested at an oral dose of 75, 150, and $300 \mathrm{mg} / \mathrm{kg}$ body weight. The ethanolic extract has displayed a significant dose-dependent antihyperglycemic activity in oral glucose tolerance test and also found to reduce the increased blood glucose in alloxan-induced diabetic rats (31\% at $150 \mathrm{mg} / \mathrm{kg}$ and $51 \%$ at $300 \mathrm{mg} / \mathrm{kg}$ body weight). Chronic administration (10 days) of the ethanolic extract of extract of root significantly reduced the blood glucose in alloxaninduced diabetic rats. The extract was also found to reduce the increased blood urea and inhibit the body weight reduction and leucopenia induced by alloxan administration. The ethanolic extract was also found to effectively scavenge the $\mathrm{DPPH}$ and lipid peroxide free radicals by in vitro type of bioassay methods with an $\mathrm{IC}_{50}$ value of 10 and $8 \mu \mathrm{g} / \mathrm{mL}$, respectively. The preliminary phytochemical examination reveals the presence of flavanoids and tannins, which may be attributed to observed antioxidant and significant antihyperglycemic properties [24-26, 45].

11.7. Antimicrobial Activity. The antimicrobial effects of petroleum ether, chloroform, and hydroalcoholic extracts of $P$. odoratissimus leaf against Bacillus subtilis, Escherichia coli, Staphlococcus aureus, and Candida albicans. In terms of antimicrobial effects, all the three extracts exhibited effective inhibition zones against gram-positive bacteria, that is, $S$. aureus, B. subtilis. However, they were ineffective against gram-negative bacteria (E. coli and $P$. aeruginosa) and fungi (C. albicans). The minimum inhibitory concentration (MIC) of hydroalcoholic, chloroform, and petroleum ether extracts was found to be 25,50 , and $50 \mathrm{mg} / \mathrm{mL}$, respectively, against gram-positive bacteria. Out of three extracts, hydroalcoholic extract showed good antimicrobial activity. The phytochemical study showed the presence of alkaloids and flavonoids in hydroalcoholic extract, which might be responsible for its good antimicrobial activity [29, 30].

11.8. Antifungal Activity. Keratophilic fungi, a type of dermatophytes, cause infection to hair, glabrous skin, and nails of human beings and animals. Soil is well known to be supporting the transient existence of them. The volatile plant oils have been of concern recently to develop a new antifungal agent. Four different commercially available Itra-Bella (Lonicera $x$ bella zabel), kewda (Pandanus odoratissimus), Rajnigandha (Polianthes tuberosa), and Mogra (Jasminum sambac) for their antifungal activity against the Aspergillus flavus, Trichophyton mentagrophytes, Trichophyton tonsurans, Trichophyton verrucosum, Epidermophyton floccosum, and Microsporum nanum were isolated from soil.

The diameters of zone of inhibition formed by Bella, Rajnigandha, kewda, and Mogra against T. tonsurans were observed to be $47 \mathrm{~mm}, 34 \mathrm{~mm}, 17 \mathrm{~mm}$, and $30 \mathrm{~mm}$, respectively, while it was $30 \mathrm{~mm}, 22 \mathrm{~mm}, 15 \mathrm{~mm}$, and $17 \mathrm{~mm}$ against the $M$. nanum. The activity was observed quite low against the Aspergillus flavus with $17 \mathrm{~mm}, 15 \mathrm{~mm}, 11 \mathrm{~mm}$, and $13 \mathrm{~mm}$ inhibitory zone shown by Bella, Rajnigandha, kewda, and Mogra, respectively, while it was intermediate against the Epidermophyton floccosum with $27 \mathrm{~mm}, 20 \mathrm{~mm}, 21 \mathrm{~mm}$, and $15 \mathrm{~mm}$ of zone inhibition. Thus, the maximum antifungal effect was shown by Bella with $47 \mathrm{~mm}$ inhibitory zone against the $T$. tonsurans, and the minimum was $11 \mathrm{~mm}$ shown by kewda against the Aspergillus flavus. Significantly, the antifungal activity shown by few Itra was comparatively better than control (antifungal drugs, Terbinafine, Itraconazole, and Fluconazole) [32].

11.9. Antiviral Activity. A lectin, designated Pandanin, was isolated from the saline extract of the leaves of P. amaryllifolius, using ammonium sulfate precipitation, affinity chromatography on mannose-agarose, and molecular size exclusion by gel filtration. Pandanin is an unglycosylated protein with a molecular mass of $8.0 \mathrm{kDa}$ both after gel filtration and on sodium dodecyl sulfate-polyacrylamide gel electrophoresis, indicating that it is a single polypeptide chain. These first isolated 10 residues of the $\mathrm{N}$-terminal amino acid sequence are DNILFSDSTL. An analysis of the sequence of first 30 amino acids at the $\mathrm{N}$-terminal region shows that Pandanin has about $50-60 \%$ the quality of being similar or corresponding in position or value or structure or function (homology) to those of mannose-specific lectins reported from monocot plants. Pandanin exhibits hemagglutinating activity toward rabbit erythrocytes, and its activity could be reversed exclusively by mannose and mannan. Pandanin also possesses antiviral activities against human viruses, herpes simplex virus type-1 (HSV-1), and influenza virus (H1N1) with 3 days of $\mathrm{EC}_{50}$ of 2.94 and $15.63 \mu \mathrm{M}$, respectively [33].

11.10. Hepatoprotective and Hepatocurative Activity. In developing countries like India, hepatic disorders are steadily increasing. Ketaki ( $P$. odoratissimus Roxb) is an important traditional medicine used in northern Karnataka (India) for jaundice. The experimental model was adopted by Watanabe and Takita (1973) to evaluate the hepatoprotective and hepatocurative activities of a Pandanus root decoction on $\mathrm{CCl}_{4}$ induced liver damage in albino rats. The degree of protective and curative activity was determined by measuring the levels of serum glutamate oxaloacetate transaminase (SGOT), serum glutamate pyruvate transaminase (SGPT), alkaline phosphatase (ALP), total serum bilirubin, and serum albumin. Histological studies and all haematological parameters 
have promoted the hepatocurative activity. Pandanus root decoction was found to be hepatocurative but not hepatoprotective $[27,28]$.

11.11. Hepatotoxic Activity. The antioxidant effect of methanol extract of $P$. odoratissimus leaf in Wistar albino rats administered with carbon tetrachloride $\left(\mathrm{CCl}_{4}\right)$ at $1.5 / \mathrm{kg}^{-1} \mathrm{CCl}_{4}$ $1 \mathrm{~mL} / \mathrm{kg}^{-1}$ in liquid paraffin 3 doses (i.p.) at $72 \mathrm{~h}$ interval. The extracts at the doses of 50 and $100 \mathrm{mg} / \mathrm{kg}^{-1}$ and (Liv-52) $25 \mathrm{mg} / \mathrm{kg}^{-1}$ were administered to the $\mathrm{CCl}_{4}$ treated rats. The effect of extract and Liv-52 on serum transaminase (GOT, GPT), alkaline phosphatase (ALP), bilirubin, and total protein were measured in the rat induced by $\mathrm{CCl}_{4}$. The effects of extract on lipid peroxidation (LPO), superoxide dismutase (SOD), catalase (CAT), glutathione (GSH), and vitamin E were estimated. The extract and Liv-52 produced significant $(P<0.05)$ effect by decreasing the activity of serum enzymes, bilirubin, uric acid, and lipid peroxidation and significantly $(P<0.05)$ increased in the level of SOD, CAT, GSH, vitamin $E$, and protein. Hence these results suggest that methanolic extract of $P$. odoratissimus has potent antioxidant properties [27].

11.12. Free Radicals Scavenging Activity. Pandanus is used in traditional use as a Ayurvedic medicines and it is also famous for its frequency. The antioxidant activity of methanolic extract of Pandanus was studied by its ability to scavenge $\mathrm{DPPH}$, nitric acid, superoxide radicals, and hydroxyl radicals. The plant extract shows antioxidant activity by $87.52 \%$ reducing the DPPH and $73.55 \%$ inhibition of nitric acid. The result also indicates maximum inhibition of superoxide radical's inhibition $74.12 \%$ and $78.14 \%$ inhibition of hydroxyl radicals. The butylated hydroxytoluene (BHT) was used as standard antioxidant [21].

11.13. Antidiuretic Activity. The ethanol and aqueous extracts of Pandanus are claimed as an antidiuretic by some traditional practitioners. Furosemide was used as a diuretic agent to induce diuresis. Vasopressin (antidiuretic hormone; ADH) was used as a standard. The results demonstrated both the ethanol and aqueous extracts of Pandanus and ADH significantly impaired the total urine output. However, antidiuretic potential of ethanol extract was similar to that of $\mathrm{ADH}$. The extracts caused a significant decrease in natriuresis and kaliuresis. It has the potential to impart therapeutic effect in diuretic [25].

11.14. Helminthic Activity. P. odoratissimus Linn. is found in the tribal area of Koraput district and extensively used traditionally by the tribal people as anthelmintic, rheumatism, stimulant, headache, and antispasmodic. The preliminary investigation of phytochemical constituents of ethyl acetate and ethanol extracts of leaves of plant $P$. odoratissimus. The two doses (25 and $50 \mathrm{mg} / \mathrm{mL}$ ) of extracts were evaluated for their anthelmintic activities on adult Indian earthworms, Pheretima posthuma. The activities are comparable with the standard drugs, piperazine citrate and albendazole. All the doses of ethyl acetate and ethanol extracts of Pandanus showed better anthelmintic activity than the standard drug albendazole except ethyl acetate extract at $25 \mathrm{mg} / \mathrm{mL}$ of concentration. The extracts of ethyl acetate at concentration of 25 and $50 \mathrm{mg} / \mathrm{mL}$ showed lesser anthelmintic activity than the standard drug piperazine citrate. When the dose of the extract is increased, a gradual increase in anthelmintic activity was observed [34].

11.15. Antitumour Activity. Antitumour activity of ethanol extract Pandanus was evaluated against Dalton's ascitic lymphoma (DAL) tumour model on dose-dependent manner. The activity was assessed using survival time, average increase in body weight haematological parameters, and solid tumour volume. Oral administration of alcoholic Pandanus extract increased the survival time and decreased the average body weight of the tumour bearing mice. After 14 days of inoculation, EPF was able to reverse the changes in the haematological parameters, protein and PCV consequent to tumour inoculation. Oral administration of EPF was effective in reducing solid tumour mass development induced by DAL cells. The results showed that EPF possess significant activity in dose-dependent manner [46].

11.16. CNS-Depressant Action. The effect of methanolic extract of $P$. odoratissimus leaf on the CNS was studied by using different neuropharmacological paradigms including spontaneous motor activity, rota-rod performance, and potentiation of Pentobarbital sodium sleeping time in albino mice. Preliminary phytochemical evaluation and acute toxicity studies were also carried out where $\mathrm{LD}_{50}>2000 \mathrm{mg} / \mathrm{kg}$ was considered nontoxic through acute exposure in rats by the oral route. The Pandanus extract (50, 100, and $200 \mathrm{mg} / \mathrm{kg}$ i.p.) produced a reduction in spontaneous motor activity, motor coordination and prolonged Pentobarbital sodium sleeping time. These observations suggest that the leaf of $P$. odoratissimus contains some active principles which possess potential CNS-depressant action [8].

11.17. Antiepileptic/Anticonvulsant Activity. Increase in latency to seizures as well as reduction in duration and frequency of seizures indicated anticonvulsant activity. The selected extract was more effective in all models used except the strychnine-induced convulsions. $P$. odoratissimus ethanol extract (100 and $200 \mathrm{mg} / \mathrm{kg}$ body wt.) significantly $(P<0.05$ to 0.01 ) shortened the duration of convulsions in maximum electroshock and picrotoxin induced seizures. Delay in the onset of convulsions in the two tests was significant $(P<$ $0.01)$. Reduction in the frequency of seizures was also significant $(P<0.05,0.01)$ in both tests. $P$. odoratissimus further delayed the onset of seizures in picrotoxin induced seizures model while producing (66.7 and $83.33 \%$ ) protection against death in mice [19].

\section{Pharmaceutical Uses}

12.1. Tannin/Dye. A black dye used in weaving is prepared from the roots in Kiribati. Charcoal from Pandanus was used in various mixtures to dye and waterproof canoes. 
12.2. Cosmetic/Soap/Perfume. Male flowers picked from uncultivated Pandanus are used alone or in combination with other flowers to perfume coconut oil in Polynesia. An exquisite, uniquely Pacific perfume is made from the aromatic fruits of selected traditional cultivated varieties in the Cook Islands. In Southland Southeast Asia, the male flowers and preparations derived from them are used to scent clothes and incorporated into cosmetics, soaps, hair oils, and incense sticks. In Hawaii, the male flowers were used to scent tapa.

12.3. Pandan Edible Colouring and Flavouring Powder. A study on the production of spray-dried pandan (P. amaryllifolius) powder was conducted and optimized using response surface methodology (RSM). Parameters investigated include inlet temperature $\left(170-200^{\circ} \mathrm{C}\right)$ and feed rate (6-12 rpm), with a preset outlet temperature of $90^{\circ} \mathrm{C}$. The estimated regression coefficients $\left(R^{2}\right)$ for the physicochemical characteristic and sensory responses of pandan powder were $\geq 0.800$, except for overall acceptability. Some mathematical models could be developed with confidence based on the results from all responses. An optimum drying process for spray drying represents conditions that would yield acceptably high colour index (such as $L$ value, $a$ value, and $b$ value), low moisture content, low water activity $\left(a_{w}\right)$, high solubility and high colour, flavour, odour, and overall acceptability for sensory responses. Optimum conditions of $170^{\circ} \mathrm{C}$ inlet temperature and $6 \mathrm{rpm}$ feed rate, with a constant outlet temperature of $90^{\circ} \mathrm{C}$, were established for producing spray-dried pandan powder as an edible colouring and flavouring powder [47].

12.4. Separation of Divalent Metal Ions. Desorption by dead biomass has been studied on P. amaryllifolius Roxb (Pandanus leaves) by conducting batch experiments. The recovery of heavy metals such as lead and copper ions from biomass was examined using a variety of desorbing chemicals. This study aims to discover the best chemical which is able to leach the metal effectively with highest desorbing capacity. The results showed that $\mathrm{HCl}$ at $\mathrm{pH} 2$ and $3.0 \mathrm{mM}$ EDTA at $\mathrm{pH} 4.58$ were effective in desorbing the copper and lead ions from the biomass. The recovery of copper is very feasible since over $90 \%$ of copper was removed from the biomass. The percentage of lead recovery is about $70 \%$. In contrast, $\mathrm{Na}_{2} \mathrm{CO}_{3}$ and $\mathrm{NaOH}$ are not effective in desorbing both of the metals. The results indicated that low $\mathrm{PH}$ is preferable for desorbing the metal ions. The binding ability of $\mathrm{HCl}$ is explained using ionexchanging principle. More concentrated protons are able to replace those ions thus regenerating the biomass. EDTA is functioning as polydentate ligands, which appear to grasp the metal between the six donor atoms. It was suggested that recovery of metal ions is mainly due to the strength of bonding between the fraction of functional group of biomass and metal ions. Recovery of the deposited metals can be accomplished because they can be released from the saturated biomass in a concentrated wash solution, which also regenerates the biomass for reuse. Desorbing chemicals such as $\mathrm{HCl}$ and EDTA have proved successful for desorbing the metal ions. Thus, biosorption of heavy metals by biomass will be emerged as one of the alternative technologies in removing the heavy metals [48].

12.5. A Natural Cockroach Repellent Activity. Seven compounds and fractions prepared from pandan leaves ( $P$. amaryllifolius) were evaluated for repellent activity against Blattella germanica Linn. using a modification of the linear tract olfactometer. 2-Acetyl-1-pyrroline, pandan essence, and the hexane-pandan extract were repellent (65-93\% repellency) at all concentrations tested; the acetone-pandan extract was attractive at increasing concentrations (minimum of $62 \%$ attractancy); artificial pandan flavouring and the dichloromethane-pandan extract gave erratic results. Undiluted crude aqueous pandan extract displayed an attractancy of $62 \%$. The potential of $P$. amaryllifolius as a natural and environmentally friendly pest management tool is discussed [49].

\section{Analytical Evaluation}

13.1. HPTLC Analysis for Polyphenols. A densitometry HPTLC analysis was performed for the development of characteristic finger printing profile. The $P$. odoratissimus methanolic extract of root was dissolved with HPLC grade methanol $100 \mathrm{mg} / 0.5 \mathrm{~mL}$. The solution was centrifuged at contents which were centrifuged at $3000 \mathrm{rpm}$ for $5 \mathrm{~min}$ and used for HPTLC analysis. Then $2 \mu \mathrm{L}$ of the samples was loaded as $7 \mathrm{~mm}$ band length in the $10 \times 10$ Silica gel 60F254 TLC plate using Hamilton syringe and CAMAG LINOMAT 5 instrument. The samples loaded plate was kept in TLC twin through developing chamber (after saturation with solvent vapor) with respective mobile phase (polyphenolic compound) and the plate was developed in the respective mobile phase (toluene-acetone-formic acid $4.5: 4.5: 1$ ) up to $90 \mathrm{~mm}$. The developed plate was dried using hot air to evaporate solvents from the plate and sprayed with stannic chloride reagent. The plate was kept Photo-documentation chamber (CAMAG REPROSTAR 3) and captured the images at UV $366 \mathrm{~nm}$. Finally, the plate was fixed in scanner stage and scanned at $254 \mathrm{~nm}$. The upsurging interest in the health benefits of the Peak table, Peak display, and Peak densitogram was identified [50].

13.2. High Performance Liquid Chromatography. Fifteen (115) compounds including ten phenolic compounds and five flavonoids were isolated from the fruits of Pandanus tectorius. All of the compounds were isolated and purified by various column chromatographies especially by semipreparative high performance liquid chromatography (HPLC). Their structures were determined under the aid of spectral methods. All compounds were isolated from this medicinal plant for the first time. The biological activities of some compounds were discussed according to the results of related literature [51].

\section{Conclusion}

The scientific research on $P$. odoratissimus suggests a huge biological potential of this plant. It is strongly believed that 
detailed information as presented in this review on the phytochemical and various biological properties of the plant might provide detailed evidence for the use of this plant in different diseases.

Pandanus odoratissimus is said to be restorative, indolent, promoting a feeling of well-being and acting as a counter to tropical climates. It may be chewed as a breath sweetener or used as a preservative in foods. It is also believed to have health-related properties, including antiviral, antiallergy, antiplatelet, anti-inflammatory, antioxidant, and anticancer action. Ayurvedic science has found the medicinal action of essential oil yielded by the screw pine's highly scented flowers to be useful in headaches, earaches and as a liniment for rheumatic pains. The distilled water from flowers is used for inducing perspiration.

It is also prescribed as a stimulant aphrodisiac and an antispasmodic agent. The flowers are powdered and included in medicines, which are either sniffed like snuff or smoked for asthma and other bronchial infections [52]. The leaves are thought to be useful in leprosy, smallpox, scabies, and diseases of the heart and brain.

Preliminary qualitative chemical studies indicated the presence of lignan, isoflavones, phenolic contents, steroids, saponin, terpenoids, glycosides, tannins, flavonoids, and phenolic in the extract. And isoflavones, polyphenol, namely, lignan, are responsible for regulating the rat fertility [17]; maybe it is helpful for the regulating and enhancing the human fertility $[17,19,53]$.

On the basis of biological activities of $P$. odoratissimus, crude extract and derived phytochemicals and their uses as pharmacological agents in traditional and modern research are possible but will first require more clinical trials and product development. The current evidence is largely limited to correlation between identified phytochemicals and mode of action for any pharmacological activity.

Mechanisms of action studies are expected to lead the way into the discovery of new agents with improved and intriguing pharmacological properties. This could be achieved by molecular modeling studies involving interaction of bioactive phytochemicals from $P$. odoratissimus with their respective molecular and therapeutic targets. The extract of $P$. odoratissimus could be further explored in the future as a source of useful phytochemicals for the pharmaceutical industry [17].

\section{Conflict of Interests}

The authors declare that there is no conflict of interests regarding the publication of this paper.

\section{Acknowledgments}

The authors are thankful to Professor T. J. Sawant Sir, founder secretary of Jayawant Shikshan Prasarak Mandal, Pune, and Dr. V. I. Hukkeri, Principal, for providing all necessary facilities to carry out the present review. Authors are also thankful to National Informatics Centre (NIC), Pune, India; Botanical Survey of India (BSI), Pune; and University of Pune, Pune, India, for contribution in this review. They thank Dr. S.D.
Ambavade, Dr. Tushar Shelke, and Dr. Sneha Prafulla Adkar, Faculty of Pharmacology Department, for their kind help and suggestion during review and research.

\section{References}

[1] K. R. Kirtikar, B. D. Basu, and E. Blatter, Indian Medicinal Plants, vol. 4, Indian Book Center, New Delhi, India, 1991.

[2] A. Charterjee and S. C. Pakrashi, The Treatise of Indian Medicinal Plants, vol. 6, National Institute of Science Communication, New Delhi, India, 2nd edition, 2001.

[3] Anonymous, The Wealth of India: Raw Materials, vol. 7, Publications and Information Directorate, Council for Scientific and Industrial Research, New Delhi, India, 1966.

[4] N. D. Prajapati, S. S. Purohit, A. Sharmak, and T. Kumar, A Handbook of Medicinal Plants, Agrobios, Jodhpur, India, 1st edition, 2003.

[5] C.-S. Wen and J.-Y. Hsiao, "Genetic differentiation of Lilium longiflorum Thunb. var. Scabrum Masam. (Liliaceae) in Taiwan using random amplified polymorphic DNA and morphological characters," Botanical Bulletin of Academia Sinica, vol. 40, no. 1, pp. 65-71, 1999.

[6] A. J. Thomson, L. Englberger, L. Guarino, R. R. Thaman, and C. R. Elevitch, Pandanus tectorius (pandanus), Species Profiles for Pacific Island Agroforestry, 2006.

[7] V. K. Raina, A. Kumar, S. K. Srivastava, K. V. Syamsundar, and A. P. Kahol, "Essential oil compostion of "kewda" (Pandanus odoratissimus) from India," Flavour and Fragrance Journal, vol. 19, no. 5, pp. 434-436, 2004.

[8] S. Rajuh, N. V. Subbaiah, K. S. Reddy, A. Das, and K. B. Murugan, "Potential of Pandanus odoratissimus as a CNS depressant in Swiss albino mice," Brazilian Journal of Pharmaceutical Sciences, vol. 47, no. 3, pp. 630-634, 2011.

[9] R. Kusuma, V. P. Reddy, B. N. Bhaskar, and S. Venkatesh, "Phytochemical and pharmacological studies of Pandanus odoratissimus Linn," International Journal of Pharmacognosy and Phytochemical, vol. 2, no. 4, pp. 171-174, 2012.

[10] N. R. Kumar, Sanjeeva, D. Padmalaxmi et al., "Antioxidant activity of methanol extract of Pandanus fascicularis Lam," Journal of Pharmacy Research, vol. 4, no. 4, pp. 1234-1236, 2011.

[11] L. Englberger, "Are Pacific islanders still enjoying the taste of pandanus?" in Pacific Islands Nutrition, vol. 58, pp. 10-11, 2003.

[12] L. Englberger, W. Aalbersberg, U. Dolodolotawake et al., "Carotenoid content of pandanus fruit cultivars and other foods of the Republic of Kiribati," Public Health Nutrition, vol. 9, no. 5, pp. 631-643, 2006.

[13] L. Englberger, W. Aalbersberg, J. Schierle et al., "Carotenoid content of different edible pandanus fruit cultivars of the Republic of the Marshall Islands," Journal of Food Composition and Analysis, vol. 19, no. 6-7, pp. 484-494, 2006.

[14] M. Murai, F. Pen, and C. D. Miller, Some Tropical South Pacific Island Foods. Description, History, Use, Composition, and Nutritive Value, University of Hawai'I Press, Honolulu, Hawaii, USA, 1958.

[15] C. D. Miller, M. Murai, and F. Pen, "The use of Pandanus fruit as food in Micronesia," Pacific Science, vol. 10, pp. 3-16, 1956.

[16] C. A. Dignan, B. A. Burlingame, J. M. Arthur, R. J. Quigley, and G. C. Milligan, The Pacific Islands Food Composition Tables, South Pacific Commission, Noumea, NC, USA, 1994. 
[17] P. P. Adkar and V. H. Bhaskar, Pharmacological evaluation of some medicinal plants for fertility [Ph.D. thesis], Vinayaka Missions University, Salem, India, 2014.

[18] S. K. Jain, Dictionary of Indian Folk Medicine and Ethno Botany, Deep Publications, New Delhi, India, 1991.

[19] P. P. Adkar, P. P. Jadhav, S. D. Ambavade, T. T. Shelke, and V. H. Bhaskar, "Protective effect of leaf extract of Pandanus odoratissimus Linn on experimental model of epilepsy," International Journal of Nutrition, Pharmacology, Neurological Diseases, vol. 4, no. 2, pp. 81-87, 2014.

[20] Sanjeeva, N. R. Kumar, D. Padmalaxmi et al., "Antioxidant activity of methanol extract of Pandanus fascicularis Lam," Pharmacologyonline, vol. 1, pp. 833-841, 2011.

[21] R. Londonkar and A. Kamble, "Evaluation of free radical scavenging activity of Pandanus odoratissimus," International Journal of Pharmacology, vol. 5, no. 6, pp. 377-380, 2009.

[22] R. Londonkar, A. Kamble, and V. C. Reddy, "Anti-inflammatory activity of Pandanus odoratissimus extract," International Journal of Pharmacology, vol. 6, pp. 311-314, 2010.

[23] A. L. Udupa, N. Ojeh, G. Gupta et al., "Analgesic activity of Pandanus fascicularis Lam.," Pharmacologyonline, vol. 2, pp. 837-840, 2011.

[24] S. Venkatesh, R. Kusuma, V. Sateesh, R. B. Madhava, and R. Mullangr, "Antidiabetic activity of pandanus odoratissimus root extract," Indian Journal of Pharmaceutical Education and Research, vol. 46, no. 4, pp. 340-345, 2012.

[25] J. Rajeswari, K. Kesavan, and B. Jayakar, "Antidiabetic activity and chemical characterization of aqueous/ethanol prop roots extracts of Pandanus fascicularis Lam in streptozotocininduced diabetic rats," Asian Pacific Journal of Tropical Biomedicine, vol. 2, no. 1, pp. S170-S174, 2012.

[26] S. Sasidharan, V. Sumathi, N. R. Jegathambigai, and L. Y. Latha, "Antihyperglycaemic effects of ethanol extracts of Carica papaya and Pandanus amaryfollius leaf in streptozotocininduced diabetic mice," Natural Product Research, vol. 25, no. 20, pp. 1982-1987, 2011.

[27] R. Londonkar and A. Kamble, "Hepatotoxic and in vivo antioxidant potential of Pandanus odoratissimus against carbon tetrachloride induced liver injury in rats," Oriental Pharmacy and Experimental Medicine, vol. 11, pp. 229-234, 2011.

[28] R. Ilanchezhian and R. Joseph, "Hepatoprotective and hepatocurative activity of the traditional medicine ketaki (Pandanus odoratissimus Roxb.)," Asian Journal of Traditional Medicines, vol. 5, no. 6, pp. 212-218, 2006.

[29] D. Kumar, S. Kumar, J. Singh, C. Sharma, and K. R. Aneja, "Antimicrobial and preliminary phytochemical screening of crude leaf extract of Pandanus odoratissimus L," Pharmacologyonline, vol. 2, pp. 600-610, 2010.

[30] M. E. Bungihan, M. G. Nonato, S. Draeger, and T. E. E. dela Cruz, "Antimicrobial and antioxidant activities of fungal leaf endophytes associated with Pandanus amaryllifolius roxb," Philippine Science Letters, vol. 6, no. 2, pp. 128-137, 2013.

[31] M. E. Bungihan, M. G. Nonato, S. Draeger, S. Franzblau, and T. E. E. dela Cruz, "Antimicrobial and antioxidant activities of fungal leaf endophytes associated with Pandanus amaryllifolius roxb," Philippine Science Letters, vol. 6, no. 2, pp. 129-137, 2013.

[32] P. Singh, R. Bundiwale, and L. K. Dwivedi, "In-vitro study of antifungal activity of various commercially available itra (Volatile plant oil) against the keratinophilic fungi isolated from soil," International Journal of Pharma and Bio Sciences, vol. 2, no. 3, pp. 178-184, 2011.
[33] S. L. Ooi, S. M. Sun, and V. E. Ooi, Purification and Characterization of a New Antiviral Protein from the Leaves of Pandanu amaryllifolius (Pandanaceae), Department of Biology, The Chinese University of Hong Kong, Shatin, Hong Kong, 2000.

[34] N. B. Shankar and J. P. Kumar, "Phytochemical screening and evaluation of anthelmintic activity of pandanus odoratissimus leafy extract," International Journal of Universal Pharmacy and Life Sciences, vol. 1, no. 1, pp. 64-71, 2011.

[35] S. R. Chilakwad, K. P. Manjunath, K. S. Akki, R. V. Savadi, and N. Deshpande, "Pharmacognostic and Phytochemical investigation of leaves of Pandanus odoratissimus Linn. f.," Ancient Science of Life, vol. 28, no. 2, pp. 3-6, 2008.

[36] T. Jong and S. Chau, "Antioxidative activities of constituents isolated from Pandanus odoratissimus," Phytochemistry, vol. 49, no. 7, pp. 2145-2148, 1998.

[37] F. Busqué, P. de March, M. Figueredo, J. Font, and E. Sanfeliu, "Total synthesis of four Pandanus alkaloids: pandamarilactonine- $\mathrm{A}$ and $-\mathrm{B}$ and their chemical precursors norpandamarilactonine-A and -B," Tetrahedron Letters, vol. 43, no. 32, pp. 5583-5585, 2002.

[38] A. Kayser, Nauru, One Hundred Years Ago. Pandanus. (trans : A. Blum), University of the South Pacific, Suva, Fiji, 2002.

[39] E. L. Little and R. G. Skolmen, Common Forest Trees of Hawaii (Native and Introduced). Agricultural Handbook 679, USDA, Washington, DC, USA, 1989.

[40] B. A. Meilleur, M. B. Maigret, and R. Manshardt, "Hala, Wauke in Hawai'i," Bishop Museum Bulletin in Anthropology, vol. 7, pp. $1-55,1997$.

[41] "Herbal Medicine: Pandan (Pandanus tectorius) Fragrant Screw Pine Fleurizon," Herbal Plant, http://www.philippineherbalmedicine.org/pandan.htm.

[42] F. B. Yahya, Extraction of aroma compound from Pandan leaf and use of the compound to enhance rice flavor [Ph.D. thesis], The University of Birmingham, 2012.

[43] D. Rosario and N. M. Esguerra, Medicinal Plants in Palau, vol. 1 of Publication 28/03 (3.0C), Palau Community College, Koror, Palau, 2003.

[44] I. E. Adam, M. J. Balick, and R. A. Lee, Useful Plants of Pohnpei: A Literature Survey and Database, Institute of Economic Botany, Bronx, NY, USA, 2003.

[45] V. Madhavan, J. C. Nagar, A. Murali, R. Mythreyi, and S. N. Yoganarasimhan, "Antihyperglycemic activity of alcohol and aqueous extracts of pandanus fascicularis lam. roots in alloxan induced diabetic rats," Pharmacologyonline, vol. 3, pp. 529-536, 2008.

[46] T. T. Mani, R. Senthil Kumar, M. Saravana, nayathulla, and B. Rajkapoor, "Antitumor activity of Pandanus odoratissimus Lam. on Daltons Ascitic Lymphoma (DAL) in mice," Hamdard Medicus, vol. 51, no. 3, pp. 27-31, 2008.

[47] K. L. Seng, Y. B. Che Man, C. P. Tan, A. Osman, and N. S. A. Hamid, "Process optimisation of encapsulated pandan (Pandanus amaryllifolius) powder using spray-drying method," Journal of the Science of Food and Agriculture, vol. 85, no. 12, pp. 1999-2004, 2005.

[48] M. Z. Abdullah and K. P. Loo, "Separation of divalent metal ions using Pandanus amaryllifolius Roxb (Pandanus) leaves: desorption study," in Waste Management and the Environment III, vol. 92, pp. 313-321, 2006.

[49] J. Li and S. H. Ho, Pandan Leaves (Pandanus amaryllifolius Roxb) As A Natural Cockroach Repellent, School of Biological Sciences, National University of Singapore, Singapore, 1926. 
[50] J. M. Sasikumar, U. Jinu, and R. Shamna, "Antioxidant activity and HPTLC analysis of Pandanus odoratissimus L. root," European Journal of Biological Sciences, vol. 1, no. 2, pp. 17-22, 2009.

[51] X. Zhang, P. Guo, G. Sun et al., "Phenolic compounds and flavonoids from the fruits of Pandanus tectorius Soland," Journal of Medicinal Plants Research, vol. 6, no. 13, pp. 2622-2626, 2012.

[52] K. R. Kirtikar and B. D. Basu, Text Book of Indian Medicinal Plants, Volume 2, pp. 3566-3569, 2000.

[53] P. P. Adkar, P. P. Jadhav, S. D. Ambavade, V. H. Bhaskar, and T. T. Shelke, "Adaptogenic activity of lyophilized hydroethanol extract of Pandanus odoratissimus in Swiss Albino mice," International Scholarly Research Notices, vol. 2014, Article ID 429828, 10 pages, 2014. 

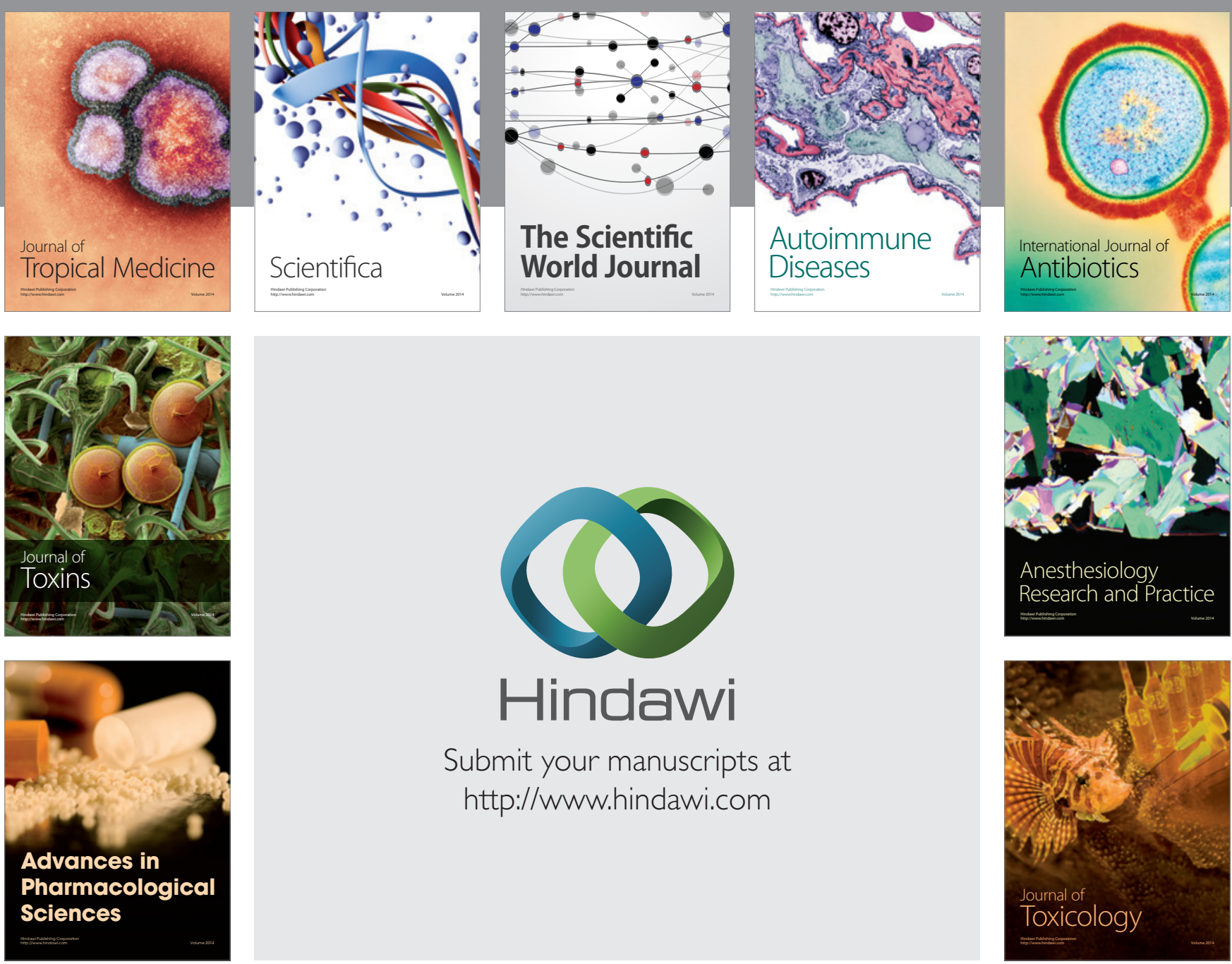

\section{Hindawi}

Submit your manuscripts at

http://www.hindawi.com
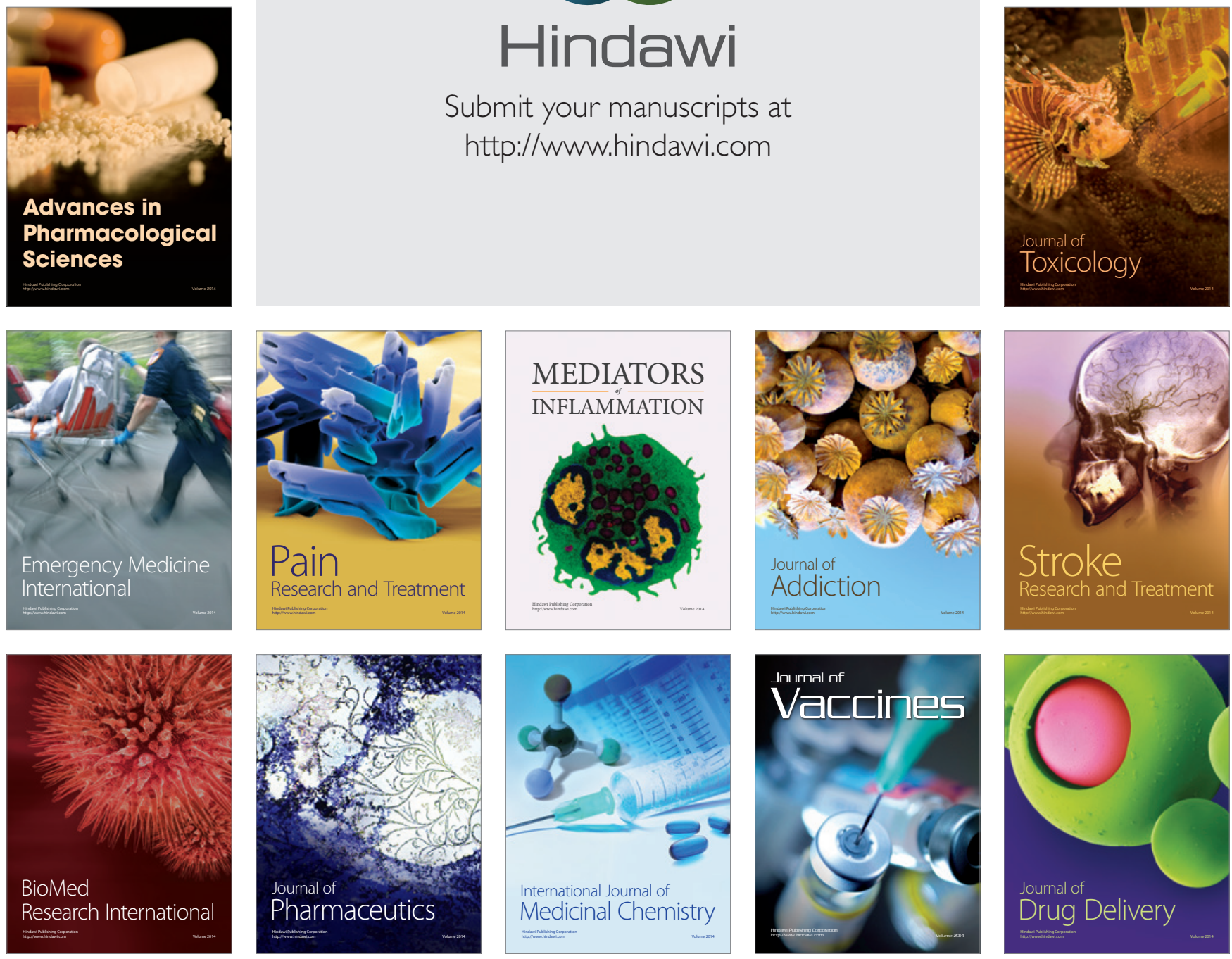